\title{
Biologically active area in low-rise high-denisty housing development with an example of Bialystok
}

\author{
Wojciech Matys \\ https://orcid.org/0000-0001-5542-8707 \\ w.matys@pb.edu.pl \\ Faculty of Architecture, Bialystok University of Technology
}

\begin{abstract}
The biologically active area is one of the most important elements of residential development. Its size is determined by the percentage factor established in local spatial development plans and laws regulations. The publication was set minimum values for this ratio for single-family and multi-family housing, and the outcomes were compared with a new type of housing, currently popular in Poland, low-rise high-density residential development. The studies were done on the example of the city of Bialystok, where there are many buildings of this new type of housing.
\end{abstract}

Key words: low-rise high-density housing development, single-family housing, multi-family housing, biologically active area, the percentage ratio

\section{Introduction}

Biologically active areas are an important and inseparable element of residential buildings and their immediate environment [Small urban dictionary, 1970]. These surfaces, together with the vegetation covering them, allow creating a favourable microclimate for the inhabitants' life [Rozanski, 1959].

In terms of function, biologically active areas belong to the group of spaces with accompanying green [Arranging green areas, 1953]. In each of the two types of residential development in Poland, the function of biologically active areas is a little different. In single-family housing, they are used for active and passive recreation for one family (private spaces). In multi-family housing, they have a recreational and aesthetic function as well as... "are intended for a short rest for all residents..., as well as being the primary playground for children..." [Korzeniowski, 1981] (open and social spaces).

Nowadays in the housing of Poland, we are dealing with a new, specific type of residential development low-rise high-density housing (Fig.1), which is being built on areas intended single-family residential.

MN
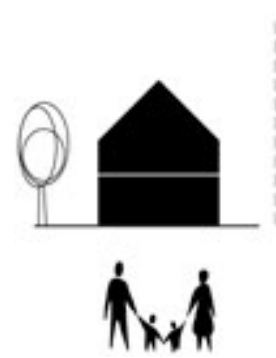

MNI
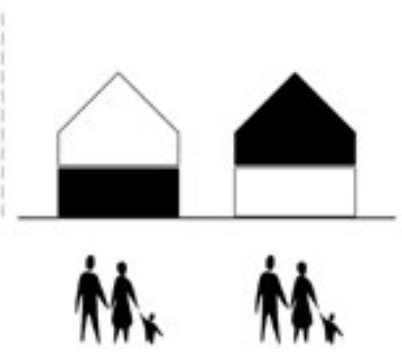
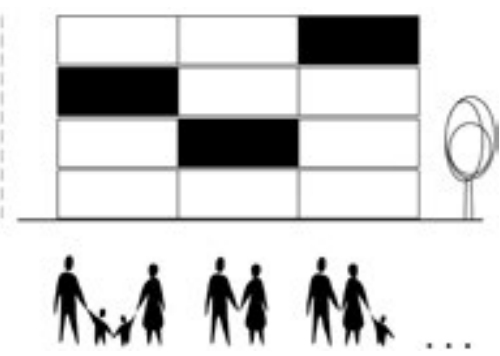

Fig. 1. Types of residential development: $\mathrm{MN}$ - single-family housing $\mathrm{MNI}$ - low-rise high-density housing, $\mathrm{MW}$ - multi-family housing; Source: author's graphic 
This type of housing development based on law regulation for single-family buildings at the same time using a legal provision [Building Law, 1994] allowing for the separation of two apartments in one segment of single-family housing. In this way, the population density in a given area increases, and hence the number of users of green areas. The nature of green areas and their function is also changing.

The publication attempts to answer the question of how can be compared the percentage factor of biologically active areas of a low-rise high-density housing development with these ratios became from existing residential development types.

\section{Materials and methods}

The definition of the biologically active area and its percentage ratio in the residential development was described based on legal regulations [Regulations of technical requirements... 2002] and city guide [Urban planner's guide 2003].

The values determining the biologically active area in residential areas were compiled on the example of Białystok, analyzing 50 local spatial development plans (based on urbanity documents available at www.gisbialystok.pl/plany). 20 of these plans concerned single-family housing and 10 of them multi-family housing. Rest of the plans (20) concerned both types of residential development. As an outcome of the analysis, the values of the percentage indicator characteristic for single-family and multi-family housing were determined.

The results were compared with the values of the percentage factor of biologically active area occurring in a new, specific type of residential development in Poland - low-rise high-density housing. The study was based on 25 examples of this new type of buildings located in Bialystok and its surroundings. These houses had to meet the criteria - the heights of an apartment - up to three floors and the numbers of residential premises in one building or segment constituting a complex of compact housing development (twin or terraced) - two apartments in back-to-back or over-and-under layout. The green area and the area of backyard terraces were taken into account. Internal road approaches and walkways to residential buildings were omitted.

The publication presents similarities and differences in the context of the biologically active area between known types of residential development and low-rise high-density housing development.

\section{Results and discussion}

\section{The Definition}

The definition of the biologically active area is contained in legal regulations apply for housing development: "ought to be understood as an area with a surface arranged in a manner providing natural plant vegetation and rainwater retention, as well as $50 \%$ of the terraces and flat roofs with the same surface and other surfaces providing natural vegetation, of an area of not less than $10 \mathrm{~m}^{2}$, as well as the surface water in this area" [Regulations of technical requirements... 2002]. A similar definition can be found in Lexicon of urban planning and spatial planning: "surface of biologically active area - native land and surface water on building plot, as well as $50 \%$ of the sum of terraces and flat roofs with an area of not less than $10 \mathrm{~m}^{2}$, arranged as permanent lawns or flowerbeds on the ground ensuring their natural vegetation." [Saternus P., 2013].

\section{Value of the percentage factor of the biologically active area}

Also in legal regulations, we can find the value of the percentage factor (25\%) of the biologically active area used, among others, in housing development. However, this provision applies only to multi-family housing. At the same time, it indicates the possibility of changing the value of the percentage ratio through the provisions of the local spatial development plan, which also determines the size of the biologically active area in the areas of single-family housing. 


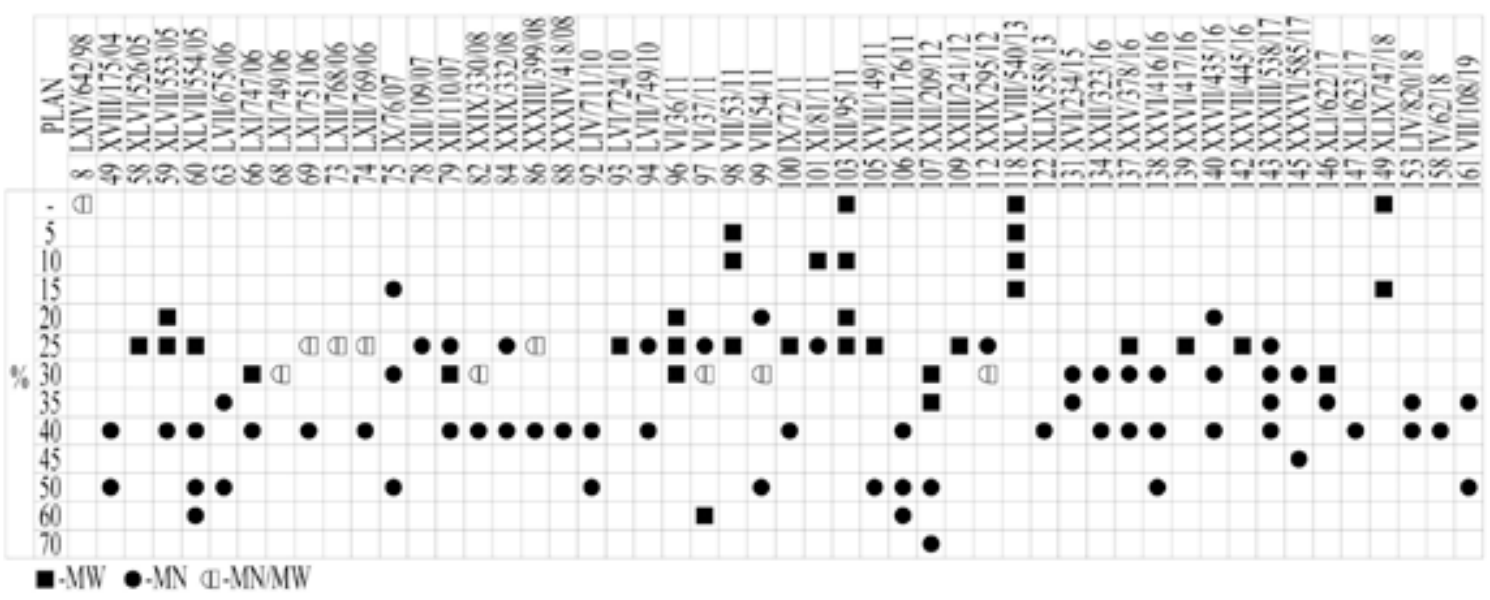

Fig. 2. Required minimum values of the percentage factor of the biologically active areas in spatial development plans in Bialystok; MN - single-family housing, including single-family compact housing (twin, terraced, group); MW - multi-family housing; Source: author's graphic

The table (Fig. 2) presents the results of an analysis of 50 local spatial development plans in Bialystok, in the context of the minimum requirements for the percentage factor of biologically active area for given types of residential buildings - single-family and multi-family. The results indicate large discrepancies in the values of required percentages within each of the types of housing development. This situation results from conditions of location (place, position in the city), the state of the existing land development (existing buildings, infrastructure) and design expectations of residents or investors. For example, in Plan No. 97, the high percentage of the biologically active area (60\%) concerns a part of areas designated for multi-family housing located near the watercourse being a tributary of the Dolistowka River. In the remaining area of the building quarter, this ratio is a minimum of $30 \%$. In turn, in the case of the oldest surveyed local spatial development plan (No. 8), the biologically active area was omitted. Only the value building area for the planned buildings is given.

The next chart (Fig. 3) shows and compares the required minimum values of the percentage ratio for single-family and multi-family housing.

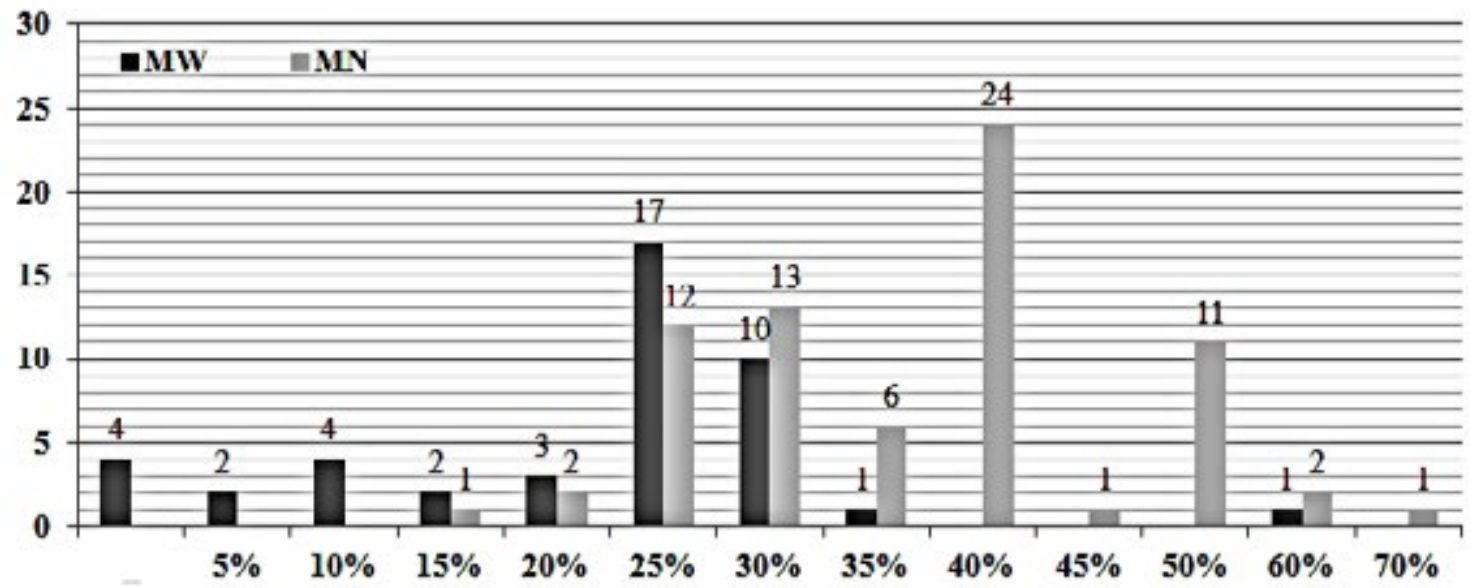

Fig. 3. Quantitative statement of values of the percentage factor in spatial development plans in Bialystok; $M N$ - single-family housing, including single-family compact housing (twin, terraced, group); MW - multi-family housing; Source: author's graphic

Based on the prepared statement, we can indicate the most commonly used minimum percentage factor for each type of residential development. In the case of single-family housing, the percentage of the biologically active surface is usually $25-40 \%$. For multi-family housing, this value is equal to the requirements contained in 
the regulations of technical requirements and amounts to $25 \%$. The values of $25 \%$ and $30 \%$ also indicate a kind of border between types of residential development. Larger values are characteristic rather for single-family housing and smaller for multi-family housing.

\section{Low-rise high-density housing development}

This type of housing construction became popular in Poland in the second half of the first decade of the $21^{\text {st }}$ century and is building in single-family housing areas. In the single-family building or segment (semi-detached or terraced), are being designed two apartments in back-to-back or over-and-under layout (Fig. 4).
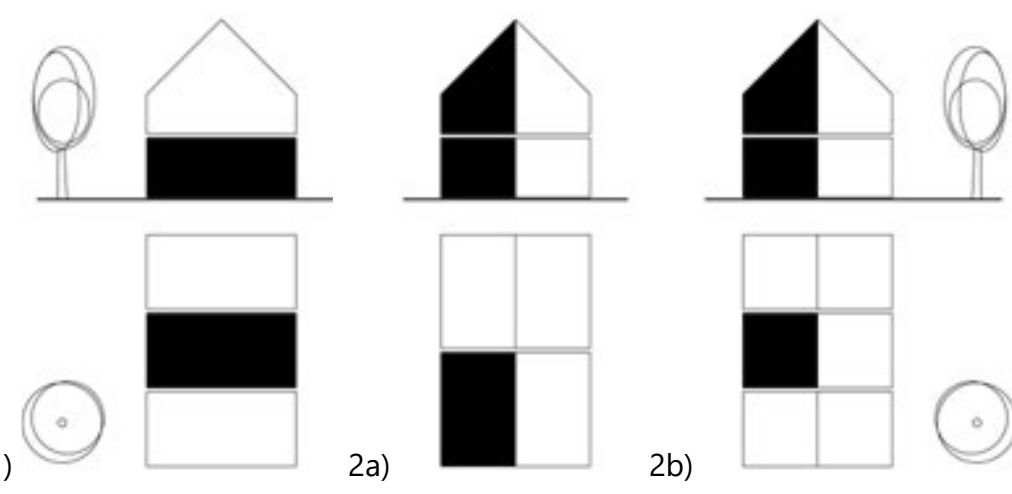

2b)

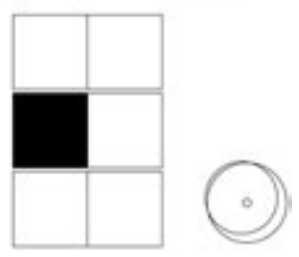

Fig. 4. Type of buildings of low-rise high - density housing :1) over-and-under flat type buildings, 2a), 2b) back-to-back residential buildings; Source: author's graphic

Besides solutions from single-family housing, we also have elements borrowed from multi-family buildings, for example, combined internal and external communication (pedestrian and vehicular), underground multi-garages under the slab, common litter bins and playgrounds. But without having to meet higher requirements for multi-family buildings (dimensions, distances).

Functionally, this type of housing is located between two known types of buildings - single-family and multi-family. We can compare it to the semi-collective buildings in Western Europe, which are characterized by 2-3 over-and-under apartments in 2-3 storey buildings. These flats also have "close although often not direct connection with green areas, which have very intimate character and belong to small built-up areas" [Seruga W., 1984].

\section{The biologically active area in low-rise high-density housing development with an example Bialystok and its surroundings.}

Low-rise high-density residential buildings have been built in Bialystok and its surroundings (Fig. 5) since 2008. In the case of the housing estate of Bialystok-Bagnowka at Ks. J. Puchalski St., this process is continuous and developmental. A specific feature of Bialystok buildings of this kind of residential development is the equal distribution of apartments layouts: over-and-under flats (13 examples) and back-to-back suites (12 examples). In Poland, instead, for the most part, there are being built flats with over-and-under configuration. 


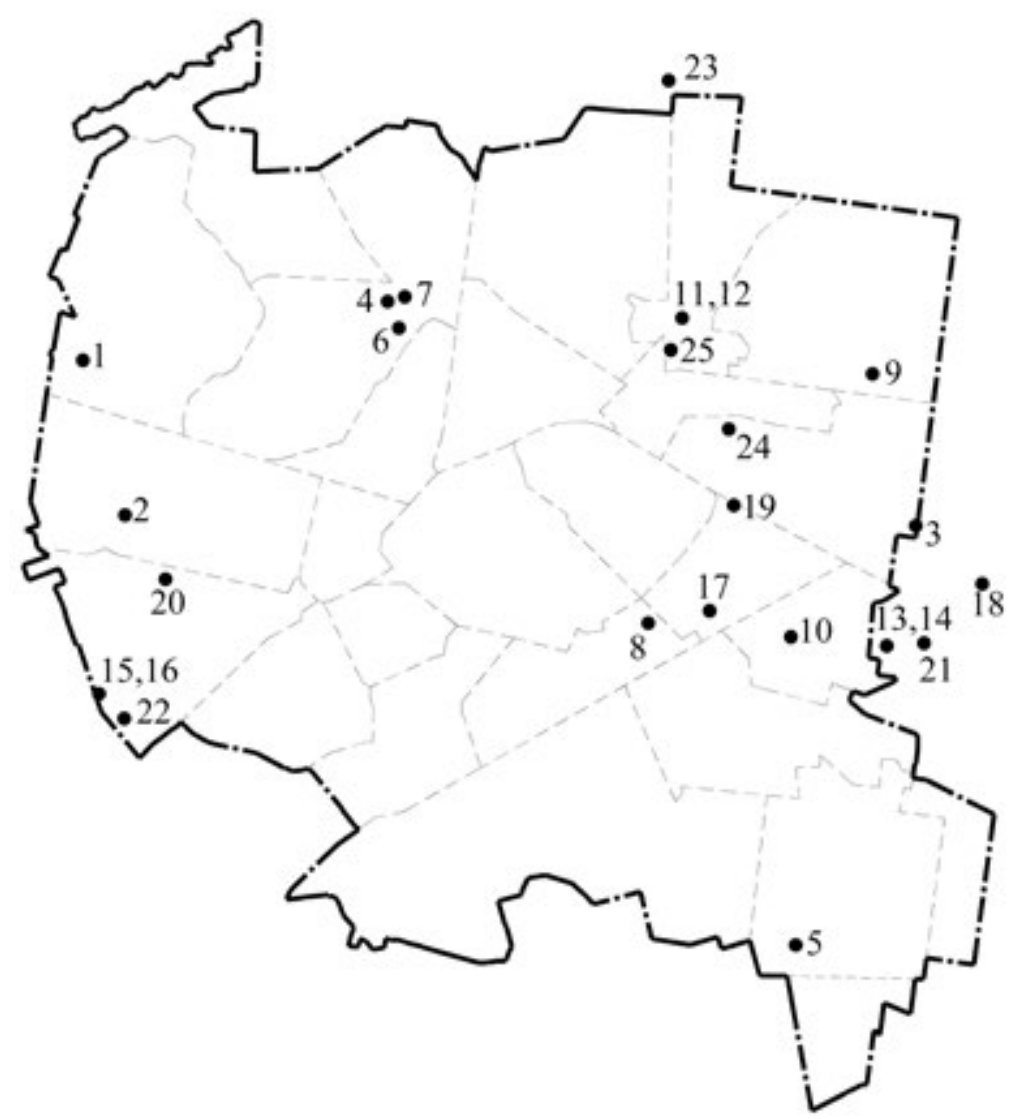

1. Bacieczki, Owocowa St.

2. Boboli St.

3. Ciolkowskiego St.

4. Cisowa St.

5. Dojlidy Gorne St.

6. Dziesieciny St.

7. Dziesieciny $90 \mathrm{St}$.

8. Jagiellonska St.

9. Ks.J. Puchalskiego St.

10. Lesna St.

11. Lacznikowa St.

12. Lacznikowa St.

13. Marcina St., Zascianki

14. Marcina St., Zascianki

15. Niewodnicka St.

16. Niewodnicka St.

17. Nowowarszawska St.

18. Palmowa St., Grabowka

19. Piasta St.

20. Rybnika St.

21. Szlachecka St., Zascianki

22. Szwajcarska St.

23. Wierzbowa St., Wasilkow

24. Zacisze St.

25. Zgody St.

Fig. 5. Location of buildings of low-rise high - density housing development in Bialystok and its surroundings; Source: author's graphic

Research on low-density, a high-density housing development in Bialystok indicates a large discrepancy in the obtained values of the biologically active area (Fig. 6). The difference between the smallest and highest percentage ratio is $37.47 \%$. The obtained average (34.96\%) coincides with the values of the percentage characteristic for single-family housing.

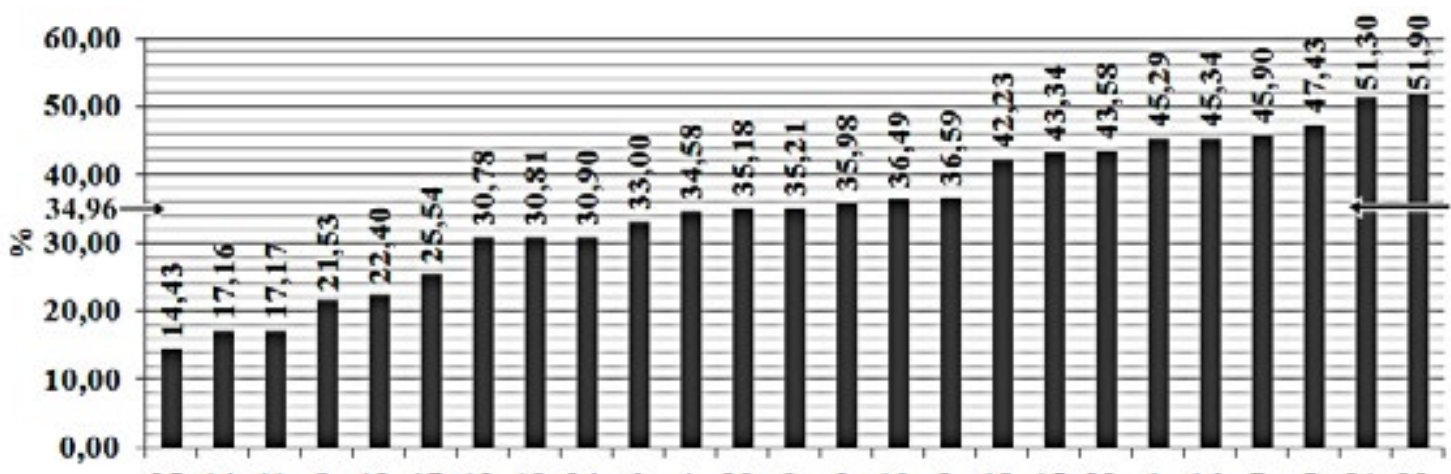

25. 14. 11. 8. 12.17. 13. 19.24. 6. 4. 20. 9. 3. 10. 2. 18. 15.22. 1. 16. 7. 5. 21. 23 . Location of buildings of low-rise high-density housing development

Fig. 6. Values of the percentage ratio biologically active areas in low-rise high-density housing development in Bialystok with an average of outcomes; Source: author's graphic 
In the case of 4 this type of buildings (locations no. 25,11,8,12), the obtained values are comparable with the results obtained in intensive multi-family housing development. The reasons for this situation should be sought in the location and shape of the plots and the building intensity. All these buildings were built on deep and narrow width plots. The buildings themselves, with a large building area, are located along with the plot with minimum distances from the plot boundaries. Leading to the apartments walkway and driveway paths extend over the entire length of the plot. That limits the size of the biologically active area, which is located on the other side of the building and usually has a width $4 \mathrm{~m}$ (minimum distance wall with windows from the fences). In the case of low-rise high-density building in location no. 14, the low percentage ratio is caused by the fact, that all biologically active area is on the construction slab (covered underground garage - the solution from multi-family housing). For this reason, the percentage factor had to be reduced by half to value $17,16 \%$, according to defined in the technical requirements.

The distribution of the percentage ratio of the biologically active areas looks similar in both configuration of apartments - the back-to-back and over-and-under (Fig. 7). But this situation is affected by the earlier described example of the location no. 14 with an underground garage, which caused the average of values percentage factor reduction. Without this case, can see that in buildings with back-to-back flats layout, are getting higher values of percentage ratio of biologically active areas. The reason for this is the structure of buildings and also the presence of four-family buildings with a large area of backyard greenery.

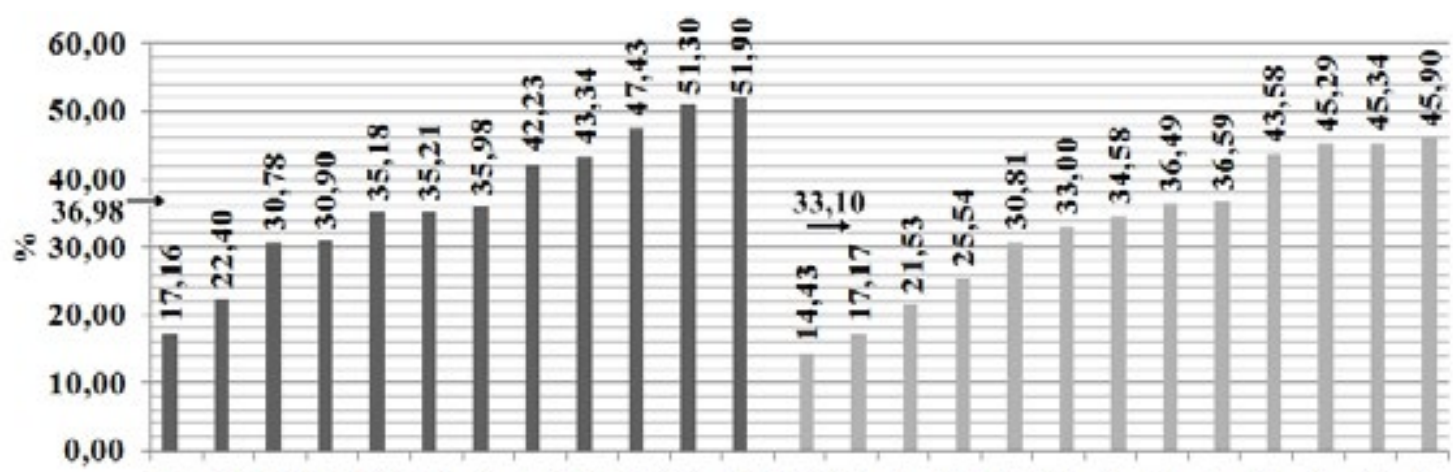

14.12.13.24. 20. 9. 3. 18.15. 5. 21.23.25.11. 8. 17.19. 6. 4. 10. 2. 22. 1. 16. 7. back-to-back layout over-and-under layout

Fig. 7. Values of the percentage ratio of biologically active areas in low-rise, a high-density housing development in the combination of two types of building: with back-to-back flats and over-and-under suites. The average results in each option; Source: author's graphic

The outcomes of the percentage factor of the biologically active area from individual low-rise high-density buildings were also compared with the records of local spatial development plans (Fig. 8). In 15 cases (locations no. $1,2,4,6,7,8,9,11,12,15,16,17,20,22,24)$, we can correlate the obtained values with spatial development plans. The percentage factor of the biologically active area is not consistent with the demands of plans in 5 sites (locations no. 4, 8, 11, 17, 20). In 3 of these (locations no. 8, 11, 17), local plans were enacted after the buildings were built. In the remaining two examples, the reason why the required minimum percentages have not been reached is unknown. 


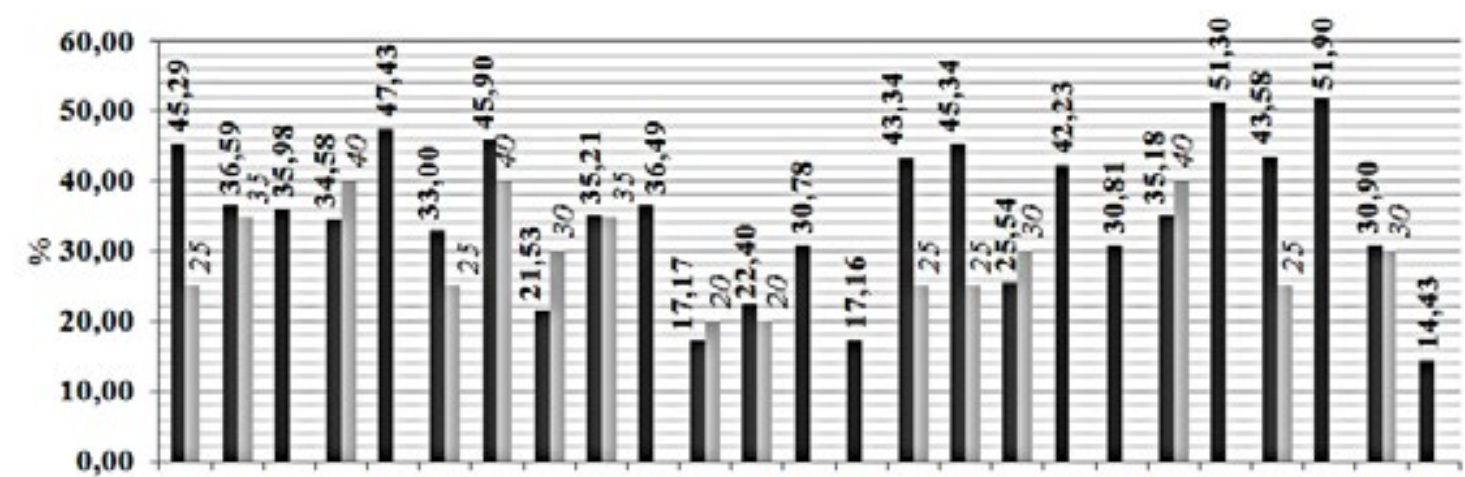

1. 2. 3. 4. 5. 6. 7. 8. 9. 10.11. 12. 13.14.15. 16. 17. 18. 19. 20. 21. 22. 23. 24.25 . - $\%$ =BAA_PLAN Location of buildings of low-rise high - density housing development

Fig. 8. Values of the percentage ratio biologically active areas in low-rise high-density housing development (\%) in comparison with the required minimum values of the biologically active area from spatial development plans (BAA); Source: author's graphic

\section{Conclusions}

The conducted research indicates that the percentage ratios of biologically active areas of low-rise high-density residential development are consistent with those required in single-family housing. In specific cases, the size of the biologically active area is reduced to values used in multi-family housing development. It caused by conditions of the location (size, shape, plot site) and/or functional solutions.

The outcomes also indicate that are influenced by the biologically active area has the layout of flats in the study buildings. The higher values of percentage factor are getting for low-rise high-density housing with the back-to-back apartments.

Although sizes of biologically active areas in low-rise high-density residential development are like in single-family housing, the nature of backyard greenery and the number of users change. As in multi-family housing, we can only talk about semi-private spaces, and in many cases even about social and open spaces (especially for apartments in an over-and-under layout).

\section{References}

[1] A collective work edited by Bieganska E., 1953: Arranging green areas (in Polish), State Technical Publisher, Warsaw

[2] A collective work edited by Zwolanowska B., 1970: Small urban dictionary (in Polish), Institute of town planning and architecture, Warsaw

[3] A collective work edited The Society of Polish Town Planners, 2003: Urban planner's guide (in Polish), Warsaw

[4] Korzeniewski W., 1981: A guide to a housing designer (in Polish), Arkady, Warsaw

[5] Ptaszycka A., 1950: Green spaces in cities (in Polish), People's Publishing Cooperative, Poznan

[6] Rozanski S., 1959: Construction of the town and its climate (in Polish), Arkady, Warsaw

[7] Saternus P., 2013: Lexicon of urban planning and spatial planning (in Polish), Bel Studio, Warsaw

[8] Seruga W., 1984: Conditions and criteria for forming low-rise high-intensive residential development (in Polish), Cracow University of Technology Publishing House, Krakow

[9] Tolwiński T., 1963: Town planning. Greenery in urban planning (in Polish), PWN, Warsaw

\section{Regulations of law}

[1] Regulation of the Minister of Infrastructure of April 12, 2002, on the technical requirements to be met by buildings and their location (Journal of Laws No. 75, item 690) as amended (in Polish) 
[2] Building Law Act of July 7, 1994 (Journal of Laws No. 89, item 414) as amended (in Polish)

[3] Spatial development plans of Bialystok (no. of plan - City Council Resolution no.): 8-LXIV/642/98, 58-XLVI/526/05, 59-XLVII/553/05, 60-XLVII/554/05, 66-LXI/747/06, 68-LXI/749/06, 69-LXI/751/06, 73-LXII/768/06, 74-LXII/769/06, 79XII/110/07, 82-XXIX/330/08, 86-XXXIII/399/08, 93-LVI/724/10, 96-VI/36/11, 97-VI/37/11, 98-VII/53/11, 99-VII/54/11, 100-IX/72/11, 101-XI/81/11, 103-XII/95/11, 106-XVIII/176/11, 107-XXII/209/12, 109-XXIII/241/12, 112-XXIX/295/12, 118-XLVIII/540/13, 137-XXV/378/16, 139-XXVI/417/16, 142-XXVII/445/16, 146-XLI/622/17, 149-XLIX/747/18

\title{
Websites:
}

[1] https://gisbialystok.pl

[2] https://www.geoportal.gov.pl

\section{Teren biologicznie czynny w niskiej intensywnej zabudowie mieszkaniowej na przykładzie Białegostoku}

\begin{abstract}
Streszczenie: Teren biologicznie czynny jest jednym z ważniejszych elementów zabudowy mieszkaniowej. Jego wielkość determinuje współczynnik procentowy ustalany w miejscowych planach zagospodarowania przestrzennego oraz regulacjach prawnych. W publikacji określono minimalne wartości tego wskaźnika dla zabudowy jednorodzinnej i wielorodzinnej, a wyniki porównano z nowym, obecnie popularnym w Polsce typem zabudowy - niską i intensywną zabudową mieszkaniową. Badania przeprowadzono na przykładzie miasta Białegostoku, w którym występuje wiele realizacji tego nowego typu zabudowy mieszkaniowej.
\end{abstract}

Słowa kluczowe: niska intensywna zabudowa mieszkaniowa, zabudowa jednorodzinna, zabudowa wielorodzinna, teren biologicznie czynny, współczynnik procentowy 